\title{
REGULATORY INCENTIVES TO PROMOTE THE USE OF PHOTOVOLTAIC SYSTEMS IN BRAZIL
}

\begin{abstract}
F. K. O. M. Varella ${ }^{1}$, C. K. N. Cavaliero ${ }^{2}$ e E. P. Silva ${ }^{3}$
${ }^{1}$ Researcher of the Interdisciplinary Center of Energy Planning, University of Campinas (NIPE/UNICAMP); and Department of Environmental Sciences and Technology, Federal Rural University of Semi-Arid (DCAT/UFERSA), Brazil

${ }^{2}$ Department of Energy, Faculty of Mechanical Engineering, University of Campinas (DE/FEM/UNICAMP), Brazil

${ }^{3}$ Department of Applied Physics, Institute of Physics "Gleb Wataghin", University of Campinas (DFA/IFGW/UNICAMP), Brazil

1fkv@ufersa.edu.br - ${ }^{2}$ cavaliero@fem.unicamp.br - ${ }^{3}$ Ih2ennio@ifi.unicamp.br

Artigo submetido em abril/2012 e aceito em junho/2012

ABSTRACT

The use of photovoltaic solar energy for electricity generation has been even more considered in many countries worldwide as an excellent alternative to reduce the man-made environmental impacts, especially those associated with climate changes. In countries such as Japan, USA, Germany, Spanish and other, specific regulatory mechanisms have been developed to stimulate its use either through governmental programs or financial and/or tax incentives. The main common motivations for the development of these programs are the diversification of the energy sources traditionally

used; the incentive to the industry of PV equipment; and the environmental concern, mainly with the reduction of $\mathrm{CO}_{2}$ emissions. In the Brazilian case, despite the large solar resource potential, many things still need to be done. Only a small number of initiatives were undertaken to encourage solar photovoltaic energy, but still very small when compared to the countries mentioned above. In this sense, this paper has the purpose of presenting the evolution of the regulatory incentives concerned to the use of photovoltaic solar energy in Brazil over the years.
\end{abstract}

KEY-WORDS: PV systems, alternative renewable energy, photovoltaic solar energy 


\section{REGULATORY INCENTIVES TO PROMOTE THE USE OF PHOTOVOLTAIC SYSTEMS IN BRAZIL}

\section{INTRODUCTION}

With the oil crisis in the 70's, when the world realized that fossil fuels are a finite resource and subjected to large supply disruptions, the limitations posed by conventional energy sources and the need to seek alternative sources of energy became clear. From then on, significant efforts were made to develop standalone or grid-connected photovoltaic solar energy systems, mainly for residential and commercial use, since that their main use was for power generation in satellites until one decade before. In fact, according to [1], such crisis boosted the development of the photovoltaic technology in Brazil, thus beginning the commercialization of photovoltaic products in the country.

From the end of the last century, the importance and utilization of alternative renewable energy sources gained prominence, this time due not only to the reduction of the reliance on fossil fuels, but mainly to environmental reasons related to climate change and its effects on the mankind. Consequently, solar energy has been arousing interest in several countries for being a technology considered clean, with reduced environmental impact when in use.

Hence, being the solar energy a source with large potential in Brazil, which can be used to generate electricity through the PV technology, this paper presents the incentives that has been provided to the use of this source over the years.

The present work initially to presents the promoting initiatives through the national programs created; tax incentives and the creation of the Brazilian Centre for Development of Photovoltaic Solar Energy - CB-SOLAR. In the following section, is presented the current status of the Brazilian Labeling Program (PBE) which aims to continuously improve the equipment related to the photovoltaic systems used in Brazil. Information about the current incentive mechanisms in other countries are also presented. At last, final remarks are made emphasizing the need of a national program to promote the use of solar photovoltaic technology.

\section{INCENTIVES TO THE USE OF PHOTOVOLTAIC SOLAR ENERGY IN BRAZIL}

\section{National programs}

According to [2], aiming to ameliorate the lack of access to electricity in several Brazilian regions, some initiatives involving photovoltaic systems for rural electrification were created together with electricity distribution companies and institution. Among them, the following are mentioned: the Solar Light Program ("Programa Luz Solar"), implemented in the state of Minas 
Gerais; Sunlight Program ("Programa Luz do Sol”), in the Northeast Region"; and the National Program for Rural Electrification (“Luz no Campo”).

Nevertheless, the first initiative that effectively incorporated the use of the photovoltaic solar energy in a national level was the Programme for Energy Development of States and Municipalities - PRODEEM² ("Programa de Desenvolvimento Energético de Estados e Municípios"), which is considered one of the largest PV-based rural electrification programs within developing countries worldwide [3]. The PRODEEM was established in December 1994 by the Brazilian government and installed approximately 9 thousand standalone photovoltaic systems. The systems were installed from June 1996 to December 2001 in all 26 Brazilian states, especially in the Northeast (semi-arid region) and North (Amazon) regions [3].

Eight years later, in April 2002, through the Law no $10.438^{3}$, reviewed by the Law no $10.762^{4}$ of November 2003, the Renewable Energy Incentive Program (PROINFA) was established under the responsibility of the Ministry of Mines and Energy (MME). The PROINFA is considered the largest Brazilian program to promote alternative energy sources for electricity generation [4].

However, the photovoltaic solar energy was not included in PROINFA's renewable energy sources portfolio. Some of the reasons are the scope of the program, conceived to provide electricity to the National Interconnected System (SIN) and the high relative cost of the technology which turns it only economically competitive at present in isolated areas. In these areas, the low energy consumption, the high dispersion of the population, the difficulty of access and the environmental constraints are conditions that make photovoltaic technology one of the adequate solutions for power supply. The photovoltaic systems can be used individually or combined with other power supply technologies (hybrid), allowing the provision of the total supply or the reduction of diesel consumption in generators [5].

Even though PV technology was not included in PROINFA, there is a statement in the Law no 10.438 itself regarding the use of the $R G R^{5}$ funds to foster photovoltaic solar energy. Indirectly one could say that this statement would be complied because the Program Light for All (LPT) ${ }^{6}$, a

\footnotetext{
${ }^{1}$ Brazil is divided in five regions: North, Northeast, Central-West, Southeast and South.

${ }^{2}$ The program was coordinated by the National Energy Development Department (DNDE), of the Brazilian Ministry of Mines and Energy (MME). The CEPEL (Electric Power Research Centre), which is a federal company located in Rio de Janeiro, was responsible for the PRODEEM's technical guidelines, comprising equipment specification for biddings, project evaluations, training of technical personnel, establishment of installation standards, verification/inspection of the installations, performance and failure analysis.

3 Provides for the expansion of electricity supply emergency, and extraordinary rate adjustment. Creates the Incentive Program for Alternative Sources of Energy (Proinfa), and the Development Account (CDE). Provides for the universalization of public power. Other measures. <www.aneel.gov.br/cedoc/lei200210438.pdf>

${ }^{4}$ Change the law 10.438, dated April 26,2002. Other measures. <www.aneel.gov.br/cedoc/lei200310762.pdf>

${ }^{5}$ Global Reverse Reserve. Created by the Law no 5.655, of 20th May 1971, "with the aim of providing funds for reversion, merger, expansion and improvements of the public electric energy services", as of its article 4‥ With the new statement given by the Law $\cong 8.631$, of 20th May 1993, the charge was postponed until 2002 and then again until the end of 2010 (Law no 10.438, of 26th April 2002).

6 The program is coordinated by MME with the participation of the holding company Eletrobrás and its subsidiaries.
} 
federal program started in 2004 aiming to universalize the access to electricity in the country, is the main beneficiary of the RGR funds, opening a big opportunity to deploy photovoltaic solar energy, especially in the Amazon and semi-arid regions [5]. However, the few projects related to its use within the LPT are insufficient to consider the program itself as a supportive program of this technology.

In 2002, the Brazilian General Accounting Office (TCU) ${ }^{7}$ elaborated a report aiming to evaluate the results obtained by PRODEEM. This report resulted in the TCU Agreement $\mathrm{n} 0$ 598/03, of May 2003, which recommended a complete restructuring of the program and determined an adequate property control. In July 2003, the process of designing the Plan for Revitalization and Capacity Building (PRC) began and the "new identity" of PRODEEM started to appear [6].

The LPT, also known as the National Program for the Universal Access to Electricity, was created by the Decree $\mathrm{n} 04.873$ of $11^{\text {th }}$ November 2003 and initially aimed to provide electricity access to the whole Brazilian rural population until 2008 [7]. However, on $28^{\text {th }}$ April 2008, the national government postponed the completion of the program until the end of 2010 by the presidential Decree $\mathrm{n}$ - 6.422. According to [8], the decision is due to the delays in some states in connecting new consumers to the grid and to the number of connection requests beyond the initial estimates. The LPT goal is to provide access to 2.5 million rural families, benefiting around 12 million people [8].

Even though PROINFA has several merits as mentioned before, it is worth mentioning again that it only encompasses medium-scale power generation connected to the National Interconnected Power Grid System (SIN). Then, there are two important legal gaps to the promotion of electricity generation by renewable energy sources in Brazil. The first gap is due to the power systems unconnected to the SIN, herein called as isolated systems; the second is due to small-scale distributed generation.

Then, it is clear that over the years Brazil has been trying to stimulate photovoltaic solar energy in order to increase its share in the Brazilian energy matrix, bringing not only social benefits, but also environmental ones. However, such incentives have not been sufficient and the country lacks some specific regulatory mechanisms to effectively foster its use.

In several countries, tax and/or financial incentives have also been used to introduce photovoltaic solar energy. Despite slow advances in this regard, Brazil has already some tax incentives to some photovoltaic equipment, as presented in the following section.

\section{Tax incentives}

${ }^{7}$ Free translation for “Tribunal de Contas da União" (TCU). 
The two most relevant taxes that have promoted the use of some photovoltaic equipment are the state-level ICMS (Tax on Services and Circulation of Goods) and the federal-level IPI (Tax on Industrialized Products). Up to December 2008, the Agreement ICMS 101/97 ${ }^{8}$ [9] provided the ICMS exemption to some equipment and components related to the use of solar and wind energy (Table 1) [10].

Table 1. ICMS-exempt photovoltaic equipment (2008)

\begin{tabular}{|c|}
\hline Equipment and components \\
\hline $\begin{array}{c}\text { Pump for liquids up to } 2 \mathrm{HP} \text { for the use in direct-current photovoltaic solar } \\
\text { energy systems }\end{array}$ \\
\hline Photovoltaic modules \\
\hline Solar cells \\
\hline
\end{tabular}

Source: adapted from Agreement ICMS 101/97.

This tax exemption is only applied to the equipment that are exempted or taxed through the Decree 3827/01 (2001) [11], which reduces to zero the IPI on several equipment and components related to electricity generation.

According to the manufacturers and retailers of photovoltaic equipment, the PV modules are the sole products currently exempted of IPI and ICMS. All PV modules currently commercialized in Brazil are imported. The purchase of inverters in the domestic market are included $12 \%$ of ICMS and in the case of charge controllers are included $12 \%$ of ICMS and $15 \%$ of IPI.

Although there is no national manufacturer of PV modules in the country, in May 2004 a technical-scientific cooperation agreement was signed for the installation of the CB-SOLAR in the facilities of the NT-Solar ${ }^{9}$, Faculty of Physics of the Pontifical Catholic University of Rio Grande do Sul (PUCRS).

\section{BRAZILIAN CENTRE FOR DEVELOPMENT OF PHOTOVOLTAIC SOLAR ENERGY: CB-SOLAR}

CB-Solar is developing a project called pilot-plant for the industrial production of national photovoltaic modules. The objective of this project is to build and evaluate this plant which will produce high-efficient, low-cost PV modules, evaluating the technical and economic feasibility of the production on industrial scale [12].

According to [13], Prof. Adriano Moehlecke, one of the coordinators of NT-

\footnotetext{
${ }^{8}$ Postponed until 31st December 2008 by the Agreement ICMS 71/08, of 4 Jul 2008. Postpones the decisions made by Agreements that conceded tax benefits. Available at: <http://www.fazenda.gov.br/confaz/> Accessed on: November 2008. This agreement is monthly renewed.

${ }^{9}$ Considered the most modern laboratory in Latin America for the manufacture of photovoltaic modules. HOLOS, Ano 28, Vol 3 
Solar, has affirmed that researches allowed the discovery of more economic feedstock and processes and that preliminary predictions indicate that it would be possible to reduce the modules costs by $15 \%$. He emphasized that the objective is to produce equipment with the same efficiency of the international competitors but at lower costs.

Beside the incentive mechanisms, it is highly relevant that all equipment that is part of a PV system take part of the Brazilian Labeling Program (PBE). The features of this program, as well as its current status, are presented in the following section.

\section{THE BRAZILIAN LABELING PROGRAM - PBE}

The National Institute of Metrology, Standardization and Industrial Quality (INMETRO) created, on $9^{\text {th }}$ February 2002, within the PBE, the Working Group on Photovoltaic Systems (GTFOT). The group was created with the objective of establishing labeling standards for the photovoltaic systems and their components, aiming to the continuous technical improvement of these products in the light of other successful programs such as for residential refrigerators, electric motors, lamps and solar water heater systems [14].

The PBE-labeled equipment of the photovoltaic systems are PV modules, inverters, charge controllers and batteries. According to [14], initially only crystalline-silicon PV modules (mono-Si or poly-Si) are being evaluated regarding to efficiency on standard test conditions (STC), mechanical resistance, water tightness and corrosion, among others. The PV modules get labels presenting their efficiency range from $A$ to $E$, being $A$ the most efficient, with an efficiency level over $14 \%$, and $E$, the less efficient, with an efficiency level below $11 \%$ [15].

The current list of PV equipment manufacturers shows that some inverter models, charge controllers and PV modules have already been tested and approved (Table 2) [16]. 
Table 2. Manufacturers and PV equipment tested and approved by PBE (February 2009)

\begin{tabular}{|c|c|c|c|}
\hline Manufacturer & Equipment & Brand & Family/Model \\
\hline \multirow{3}{*}{$\begin{array}{l}\text { UNITRON* Engenharia } \\
\text { Ind. e Com. Ltda }\end{array}$} & \multirow[t]{2}{*}{ Inverter } & PROSINE & $\begin{array}{l}\text { SW 1000i; SW 1800i; } \\
\text { XS 1000; XS } 1800\end{array}$ \\
\hline & & UNITRON & $300 S P-12-220$ \\
\hline & Charge controller & UNITRON & $\begin{array}{c}\text { TOTAL CONTROL TC } \\
1212\end{array}$ \\
\hline \multirow{4}{*}{$\begin{array}{l}\text { ORBE Brasil Ind. e Com. } \\
\text { Ltda }\end{array}$} & \multirow{4}{*}{ Inverter } & \multirow{4}{*}{ ORBE } & ICS-500-024-127-1G01 \\
\hline & & & \\
\hline & & & ICS-300-012-127-1G03 \\
\hline & & & ICS-300-012-220-1G04 \\
\hline PHOCUS AG & Charge controller & PHOCUS & CX10; CX20; CX40 \\
\hline Acumuladores MOURA & Battery & MOURA & $12 \mathrm{MC} 150 \mathrm{M}$ \\
\hline \multirow{2}{*}{$\begin{array}{l}\text { KYOCERA Solar do Brasil } \\
\text { Ltda }\end{array}$} & Charge controller & MORNINGSTAR & $\begin{array}{l}\text { SS10; SHS10; PS15; } \\
\text { PS30 }\end{array}$ \\
\hline & PV module & KYOCERA & $\begin{array}{c}\text { КС50T; КС65T; КС85T; } \\
\text { КС130TM }\end{array}$ \\
\hline
\end{tabular}

Source: [16].

Within the current tested and approved equipment, as shown in Table 2, ORBE Brasil and Acumuladoras Moura are national manufacturers, being the former inverters producers and the latter battery producers. From the four tested PV modules of Kyocera Brasil, one got A and the other three B [15].

\section{INTERNATIONAL REGULATORY MECHANISMS TO INCENTIVE THE USE OF PHOTOVOLTAIC SYSTEMS}

The use of photovoltaic solar energy has been intensified in several countries due to governmental incentives, especially through specific national programs. The main common motivations for the development of these programs are the diversification of the energy sources traditionally used, the incentive to the industry of PV equipment and the environmental concern, mainly with the reduction of $\mathrm{CO}_{2}$ emissions.

Within the existent PV incentive programs, those from Germany, Japan and Florida (USA) are prominent as the world largest, despite other important programs in countries like Italy and 
Spain. Figure 1 shows the growth of the accumulated installed systems in Germany, Japan and California, from which the relation between this growth and the introduction of incentive programs can be seen.

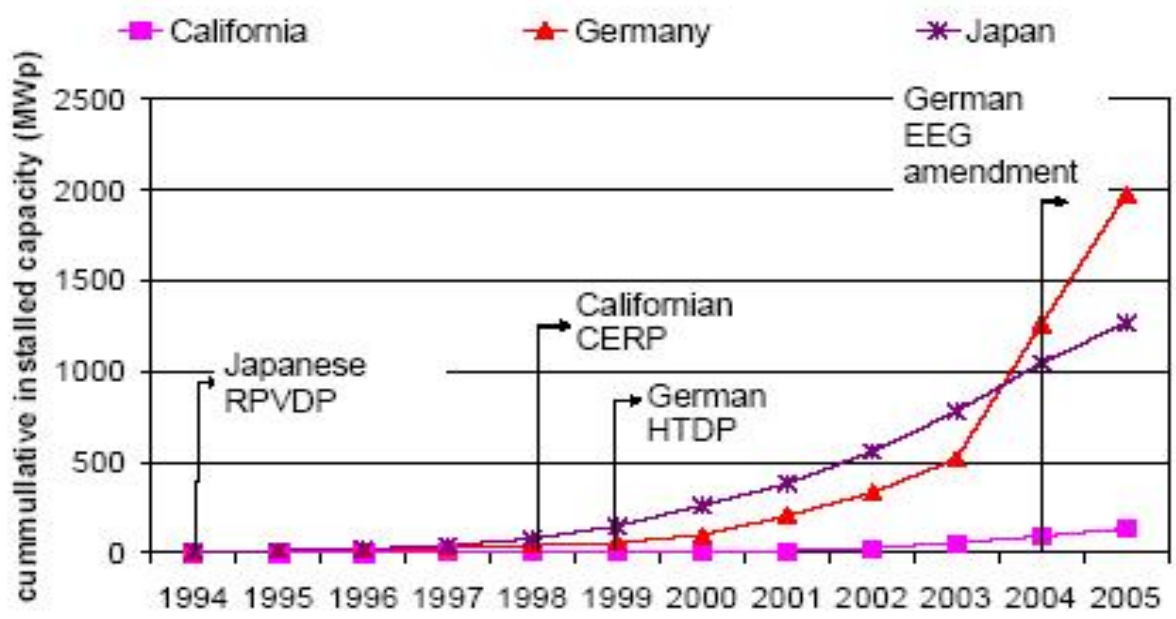

Fig. 1. Accumullated installed capacity in $\mathbf{M W}_{\mathrm{p}}$ of the largest world grid-connected PV systems incentive programs ${ }^{10}$

Source: [18].

As shown by Figure 1, the implementation of the Renewable Energy Sources Act (EGG) in Germany, which came into force in 2004, promoted a considerable growth in the domestic installed capacity of PV systems. From then on, Germany started to be considered as the country with the world largest annual installed capacity growth of PV systems [17].

Tables 3, 4 and 5 present the main incentive programs carried out in these three standout largest markets. One can notice that such programs have been managing to increase the share of PV systems in the power generation, either through governmental subsidies or specific incentive mechanisms.

Table 3. Main incentive programs to the use of photovoltaic systems in Japan

\begin{tabular}{lll}
\hline $\begin{array}{c}\text { Country } \\
\text { Japan }\end{array}$ & Program & Description \\
\hline
\end{tabular}

\footnotetext{
${ }^{10}$ Japanese RPVDP: Japanese Residential System Dissemination Program ou Residential PV System Dissemination Program; Californian CERP: California's Emerging Renewables Program; German HTDP: German 100.000 roofs Program; EGG: German Renewable Energy Sources Act.
} 
Launched in 1994, it was renamed Residential PV

Japanese Residential

System Dissemination

Program or Residential

PV System Dissemination

Program - RPVDP (1994-

2005)

Basic Act on Energy

Policy (Energy Policy

Law) (2002) and New

Energy Innovation Plan

(2006)

Japanese Field Test

Project (2007)
System Dissemination Program (RPVDP) in 1997

[17]. Created with the aim of developing the residential PV market, the program subsidized the installation of residential PV systems [17, 18, 19].

From 1994 to 2005, 253,752 PV systems were installed, totaling 931,575 kW. This program strongly contributed to the creation of the residential market for PV systems in Japan [17, 20].

The Japanese energy policy and measures, including PV power generation, is based on the Basic Act on Energy Policy (Energy Policy Law), which came into force in 2002. It establishes three principles: to secure a stable energy supply; environmental suitability and the use of market mechanisms. The dissemination of PV systems is defined in the "New Energy Innovation Plan" under the "New National Energy Strategy", which founded the Japanese energy strategy laid out in 2006 [19].

In 2007, seven demonstration programs were implemented in Japan. One of them is the Field Test Project on New Photovoltaic Power Generation Technology (IEA/PVPS, 2007). All programs were specifically created to promote the large scale installation of PV systems in the commercial and industrial sectors and in other non-residential applications. In 2006, the budget of 11.8 billion yens was allocated only for this purpose [18].

Table 4. Main incentive programs to the use of photovoltaic systems in Germany

Country Program Description




\begin{tabular}{|c|c|c|}
\hline erman & & \\
\hline & $\begin{array}{l}\text { The German 1,000 } \\
\text { roofs Program } \\
(1989-1994)\end{array}$ & $\begin{array}{l}\text { First national PV system program with international } \\
\text { dissemination. 2,250 PV systems were installed on } \\
\text { the German residential rooftops. The total installed } \\
\text { capacity was around } 6 \mathrm{MW} \text {. Subsidies of } 70 \% \text { on } \\
\text { average of the investment costs were paid [18]. }\end{array}$ \\
\hline & $\begin{array}{l}\text { German } 100,000 \\
\text { roofs Program } \\
\text { HTDP }(1999-2003)\end{array}$ & $\begin{array}{l}\text { Considered the largest program in the world to } \\
\text { introduce the photovoltaic solar energy [22], the } \\
\text { program turned loans available to the population as } \\
\text { an incentive to install grid-connected PV systems. } \\
\text { From January } 1999 \text { to June } 2003 \text {, approximately } 66 \\
\text { thousand systems were installed, totaling more } \\
\text { than } 300 \mathrm{MWp} \text { of installed capacity [23]. This } \\
\text { support scheme has been continued by a program } \\
\text { called Solarstrom Erzeugen [18]. }\end{array}$ \\
\hline & $\begin{array}{l}\text { Renewable Energy } \\
\text { Sources Act } \\
{ }^{\text {(a) }} \text { - EGG }\end{array}$ & $\begin{array}{l}\text { Initially, the financial incentive to promote the use } \\
\text { of alternative energy sources started through the } \\
\text { Electricity Feed-In Law (EFL), enacted in } 1991 \text {. This } \\
\text { law had a national scope and defined the obligation } \\
\text { of energy concessionaries to buy a certain amount } \\
\text { of energy generated by alternative energy sources } \\
\text { [18, 24, 25, 26]. In 2006, EFL was replaced by the } \\
\text { Renewable Energy Sources Act (EGG), a new } \\
\text { legislation related to power generation from } \\
\text { renewable energy sources. From then on, all power } \\
\text { suppliers that operate power grids for public supply } \\
\text { (called grid operators) were obligated to buy all } \\
\text { electricity generated from renewable energy } \\
\text { sources [18, 24, 25, 26, 27]. In 2004, the } \\
\text { remunerations and goals were revised and a specific } \\
\text { law was amended to EGG, determining special } \\
\text { remunerations for these projects as a function of } \\
\text { the installed capacity [25, } 27 \text { ]. The tariffs for new } \\
\text { installed PV systems started to be yearly reduced by } \\
5 \% \text { for a } 20-y e a r \text { operation period [18, } 19,26] \text {. }\end{array}$ \\
\hline
\end{tabular}

(a) Considered the most important incentives for the growth of the German PV systems market. 
Table 5. Main incentive programs to the use of photovoltaic systems in California/USA

\begin{tabular}{|c|c|c|}
\hline Country & Program & Description \\
\hline & $\begin{array}{l}\text { California's } \\
\text { Emerging } \\
\text { Renewables } \\
\text { Program - CA ERP } \\
(1998)\end{array}$ & $\begin{array}{l}\text { After the deregulation of the electric energy public } \\
\text { services in 1998, the California Energy Commission } \\
\text { was placed in charge of the new renewable energy } \\
\text { program. The aim of this program was to increase } \\
\text { the total production of electricity from renewables } \\
\text { statewide and such support contributed to make } \\
\text { California a recognized leader in the field [28]. }\end{array}$ \\
\hline & $\begin{array}{l}\text { Renewable Portfolio } \\
\text { Standard Program - } \\
\text { RPS (2002) }\end{array}$ & $\begin{array}{l}\text { In 2002, California established the Renewable } \\
\text { Portfolio Standard Program with the objective of } \\
\text { increasing the share of renewable energy sources in } \\
\text { the state energy matrix to } 20 \% \text { until } 2017 \text {. It is } \\
\text { worth highlighting that within the regulatory } \\
\text { mechanism currently in place to promote the use of } \\
\text { alternative energy sources in the US, the RPS is one } \\
\text { of the most adopted programs by the American } \\
\text { states, which is a set of market mechanisms aiming }\end{array}$ \\
\hline $\begin{array}{c}\text { USA } \\
\text { (California) }\end{array}$ & $\begin{array}{l}\text { California Solar } \\
\text { Initiative }^{(b)}-\text { CSI } \\
(2006)\end{array}$ & $\begin{array}{l}\text { Considered as one of the largest incentive programs } \\
\text { in the US [17], the California Solar Initiative (CSI), } \\
\text { created in 2006, was formulated by the California } \\
\text { Public Utilities Commission, providing rebates for } \\
\text { residential consumers that buy electricity generated } \\
\text { from renewable energy sources. This incentive } \\
\text { program began in } 2007 \text { and provided US\$ } 3.3 \text { billion } \\
\text { over ten years for renewable systems of less than } 1 \\
\text { MW [28]. }\end{array}$ \\
\hline
\end{tabular}

(b) Because there are several state incentive programs in U.S., for further details of these programs and current federal subsidies, the authors suggest accessing the following website: http://www.dsireusa.org.

Although motivated by common rationales, as already mentioned, each country adopted its own incentive schemes. But even so, it becomes clear that all schemes converged to the obligation of acquiring energy from PV systems or other alternative renewable energy sources.

In the Brazilian case, the few initiatives in this direction are not sufficient to affirm that the country has any effective incentive at all to promote photovoltaic solar energy. The few incentives for photovoltaic solar energy through promotion programs was obtained by the Programme for Energy Development of States and Municipalities (PRODEEM), which installed 5.2 
MWp from June 1996 to December 2001, a tiny amount compared to those countries that, within their priorities, promote policies to introduce such energy source.

The total PV installed capacity in Brazil is estimated to be $30 \mathrm{MW}_{\mathrm{p}}$, from which $70 \%$ are located in the North, Northeast and Center-West regions. The majority of the PV systems installed aimed to rural electrification and water pumping, meeting the electricity demands that are distant from the conventional power grid, normally in rural areas where photovoltaic solar energy is, most of the time, considered the best technological option.

It clearly shows the difference between the applications used in Japan, European countries and U.S., and those in Brazil, because while in Brazil grid-connected PV systems are not being commercially used yet, these systems dominate the PV market in those countries.

\section{CONCLUSIONS}

As observed, Brazil has been trying to stimulate the use of PV solar energy over the years, through some incentive programs in order to increase its participation in the national energy matrix. However, unfortunately such incentives were not sufficient to promote the intensive use of this energy source, even considering the country's large solar energy potential.

Even though this paper showed that Brazil has already some tax incentives exempting some photovoltaic equipment from some taxes, the country still needs a specific regulatory mechanism if the intention is to expand the share of this source in the national energy matrix, as shown by the successful programs of Japan, Germany and California.

It is worth mentioning that differently of those countries, the PV systems used until now in Brazil are standalone systems (rural electrification and water pumping systems), installed in isolated communities and rural areas mainly as research projects carried out by many public institutions. It occurs because grid-connected PV systems are not economically feasible yet to compete with the current electricity tariffs to consumers.

All this shows that, to expand the use of photovoltaic solar energy in Brazil, with the subsequent diversification of its energy matrix, measures should be taken meeting the country specific conditions. The successful programs implemented in Japan, Germany and U.S. (especially in California) can be used as references to the elaboration of a national PV solar incentive program, but always taking into consideration the characteristics of the systems used in Brazil, the population to be benefited as well as the differences of the systems installed in those countries, the great majority grid-connected PV systems.

\section{REFERENCES}

[1] Fraidenraich, N., 2005. Antecedentes Históricos da Ciência Solar no Brasil. A Tecnologia Solar Fotovoltaica ("Hystorical background od the Solar Science in Brazil. The photovoltaic solar technology"). Grupo de Pesquisas em Fontes Alternativas de Energia. FAE. UFPE. 2005. 
[2] Winrock International - Brazil., 2002. Trade Guide on Renewable Energy in Brazil. October 2002.

[3] Galdino, M. A. \& Lima, J. H. G., 2002. PRODEEM - O Programa Nacional de Eletrificação Rural Baseado em Energia Solar Fotovoltaica ("PRODEEM - The National Rural Electrification Program Based on Photovoltaic Solar energy"). CEPEL - Centro de Pesquisas de Energia Elétrica. Congresso Brasileiro de Energia 2002.

[4] MME., 2006. Programa de Incentivo as Fontes Alternativas de Energia Elétrica - PROINFA ("Renewable Energy Incentive Program - PROINFA"). Available at: <http://www.mme.gov.br/programs_display.do?prg=5> Accessed on: abr 2006.

[5] Porto, L., 2007. Comunicação via e-mail ("Personnal communication by e-mail”). Diretora do Departamento de Desenvolvimento Energético e Coordenadora da Sala de Monitoramento do PROINFA ("At the time, the Director of the Energy Development Department of the Ministry of Mines and Energy and Coordinator of PROINFA Monitoring"). November 2007.

[6] MME., 2005. Ministério de Minas e Energia. Relatório Sumário Executivo das Atividades Desenvolvidas pelo Programa de Desenvolvimento Energético de Estados e Municípios (PRODEEM) ("Executive summary of the activities developed by the Programme for Energy Development of States and Municipalities - PRODEEM"). From June 2003 to December 2004. January 2005.

[7] Eletrobrás., 2008. Programa Luz para Todos (“Program Light for All”). Available at:

<http://www.eletrobras.gov.br/elb/portal/data/Pages/LUMIS32AB99AAPTBRIE.htm>. Accessed on: April 2008.

[8] Agência Canal Energia., 2008. Governo prorroga prazo de conclusão do Luz para Todos para 2010 ("The Government postpones the completion of the Program Light for All to 2010"). Available at: <http://www.canalenergia.com.br> Accessed on: April 2008. In Portuguese.

[9] Convênio ICMS 101/97, de 12 de dezembro de 1997. Concede isenção do ICMS nas operações com equipamentos e componentes para o aproveitamento das energias solar e eólica que especifica ("Concedes ICMS exemption for equipment and components related to the use of solar and wind energy"). Available at: <http://www.fazenda.gov.br/confaz/confaz/Convenios/ICMS/1997/cv101_97.htm> Accessed on: April 2008.

[10] Varella, F. K. O. M., 2009. Estimativa do Índice de Nacionalização dos Sistemas Fotovoltaicos no Brasil. Universidade Estadual de Campinas - UNICAMP. 2009. 148 p. (Tese de Doutorado). Campinas: FEM, UNICAMP, 2009. Faculdade de Engenharia Mecânica, Universidade Estadual de Campinas, 2009.

[11] Decreto $n^{\circ} 3827 / 01$, de 21 de maio de 2001. Reduz a zero o IPI sobre diversos equipamentos e acessórios destinados a geração de energia elétrica ("Reduces to zero the IPI on several equipment and accessories used for power generation"). Available at: <http://www.fisconet.com.br/user/legis01/decreto/3827.htm> Accessed on: April 2008. 
[12] CB-SOLAR., 2008. Centro Brasileiro para Desenvolvimento da Energia Solar Fotovoltaica. Available at: < http://www.pucrs.br/cbsolar/ntsolar/index.htm> Accessed on: Nov 2008.

[13] Agência CT., 2008. MCT. Ministério de Ciência e Tecnologia. Pesquisa reduz custo de equipamentos de geração de energia solar ("Research reduces the cost of PV systems equipment"). Available at: <http://agenciact.mct.gov.br/index.php/content/view/47757.html> Accessed on: abr 2008. In Portuguese.

[14] CRESESB., 2007. Centro de Referência para Energia Solar e Eólica Sérgio de Salvo Brito. Informe CRESESB. CB-Solar produz células solares de alta eficiência ("CB-SOLAR produces highefficient solar cells"). p. 18. № 12. October 2007.

[15] Procel Info., 2008. Centro Brasileiro de Informação de Eficiência Energética. Pioneirismo na Etiquetagem de Sistemas Fotovoltaicos: Procel e Universidade de São Paulo inauguram laboratório que vai fazer classificação da eficiência energética de módulos fotovoltaicos ("Pioneering Labelling of Photovoltaic Systems: Procel and University of São Paulo inaugurate laboratory that will rank the energy efficiency of PV modules"). Available at: <http://www.procelinfo.com.br>. Accessed on: June 2008.

[16] INMETRO., 2009. Instituto Nacional de Metrologia, Normalização e Qualidade Industrial. Programa Brasileiro de Etiquetagem. Componentes de Sistemas para Energia Solar Fotovoltaica. Edição 01/09, de 16 de fevereiro de 2009. Available at: <http:// http://www.inmetro.gov.br/consumidor/pbe/CompFotovoltaico.pdf> Accessed on: may 2009.

[17] PVPS Annual Report 2006., 2006. IEA, 2006.

[18] Haas, R.; Demet, S.; Lopez-Polo, A., 2006. An International Comparison of Market Drivers for Grid Connected PV Systems. 21st European Photovoltaic Solar Energy Conference, 4-8 september 2006. Dresden, Germany.

[19] PVPS Annual Report 2007., 2007. IEA, 2007.

[20] Ikki, O; Tanaka, Y., 2004. National Survey Report of PV Power Applications in Japan 2003. IEA, 2004.

[21] Ikki, O; Matsubara, K., 2007. National survey report of PV Power Applications in Japan and Japan: PV Technology and Prospects. PVPS Annual Report 2007. IEA, 2007.

[22] Scheer, H., 1999. Germany's 100,000 Roof Photovoltaic Programme. 1999.

[23] Stubenrauch, F., 2003. National Survey Report of PV Power Applications in Germany 2003. IEA, 2003.

[24] EREC., 2004. European Renewable Energy Council. Renewable Energy Policy Review Germany. 2004.

[25] Cavaliero, C.K.N.; Silva, E.P.; Araújo, P.D.; Teixeira, A.F., 2004. Mecanismos Regulatórios para Geração de Energia Elétrica a Partir de Fontes Renováveis Alternativas de Energia ("Regulatory mechanisms for power generation from alternative renewable energy sources"). September 2004. Projeto de pesquisa financiado pelo Ministério de Minas e Energia do Brasil. 
[26] Wissing, L., 2006. National Survey Report of PV Power Applications in Germany 2006. IEA, 2006.

[27] Cavaliero, C.K.N.; Silva, E.P., 2003. Considerações sobre a inserção das fontes renováveis alternativas de energia ("Consideration concerning the introduction of alternative renewable energy sources"). III Congresso Brasileiro de Regulação de Serviços Públicos Concedidos, 2003. Anais... Gramado/Rio Grande do Sul, 2003.

[28] CEC., 2008. Califórnia Energy Commission. Renewable Energy Program. Available at: <http://www.energy.ca.gov/renewables/index.html>. Accessed on: junho 2008. 